\title{
Teaching and Learning About Unconventional Food Plants in an Edible Urban Landscape: A Brief Report
}

\author{
Neide Rigo
}

\section{Contents}

References

My interest in edible plants is an old one, and I have always dedicated myself to being aware of the edible landscape around me. I like taking walks with the purpose of discovering edible plants in the urban space, either planted or spontaneously sprouted. In 2012, I wanted to do something special for December 10, when the Slow Food movement celebrates Terra Madre Day internationally. So, I decided it would be pleasant and productive to share my experience with other people. I gathered friends and strangers through an invitation on my blog, ${ }^{1}$ and equipped with bags, scissors, and paraphernalia for gathering plants, we were 12 people roaming around the streets of my neighborhood. We walked for about $3 \mathrm{~h}$, and the result could not have been any better. We brought home fruits, edible flowers, leaves, and roots, as well as aromatic plants, which were all prepared collectively for lunch. When eating, each with their own plate on their lap, the feeling was of enchantment for understanding oneself as part of a system surrounded by good and free food that no one notices in the rush of everyday life.

I repeated the experience a few more times, whenever I had the time. Many of the people who took part in these sporadic foraging events were insistently asking for more gatherings, and I myself found the activity much more exciting when I had the company of others who shared the same interest, so I decided that I could turn these outings into a job. In 2016, PANC na City was officially born as a guided foraging tour to observe, identify, and possibly harvest every kind of unconventional food

\footnotetext{
${ }^{1}$ See at www.come-se.blogspot.com. See also my Instagram account @ neiderigo.
}

N. Rigo $(\bowtie)$

Autonomous Researcher, São Paulo, SP, Brazil 
plants (UFP) that we found along the way. It happened in the City Lapa neighborhood, located in the western part of São Paulo. It was initially planned to be a monthly event, and for a long time, I was able to do so. Over the past 2 years (since 2018), I tried to keep the project alive with at least six tours a year. Forages were always preceded by a talk and an exposition of dozens of forgotten, unknown, or neglected edible species. After that, our lunch was prepared using several of the plants observed, some found in the streets, other cultivated in my yard. Having different people signing up for each forage is a source of enjoyment, but besides that, it is great to have the opportunity to observe the changing of the species throughout the different seasons in the year, a fact rarely noticed in a world used to just a few mainstream vegetables artificially available at all times in the market. One of the stops of the tour is at Horta (kitchen garden, in Portuguese) City Lapa, a space full of perennial species, either edible, aromatic, or medicinal.

Our community garden was born in 2014 from a group of neighbors outraged by the sad fate of a small piece of land of about 170 square meters (Fig. 1). This corner looks like it was a remnant of the block, and although sitting between two wide streets full of trees, it was used as a disposal point for rubbish, pruning remains and broken furniture. All this waste was thrown amid high grass, lacking proper maintenance by the neighborhood council, and because of these features, the place was considered dangerous, and residents would avoid passing by.

Trying to transform that idle and poorly maintained space, one other neighbor and I started to plant useful species and organize ideas and actions to make that space more friendly. We set up a meeting and invited as many people from the neighborhood as we could, but only the two of us attended. So, without much support from the community in that first moment, we went to the neighborhood council to ask for help to clean the space. In that same week, a truck of workers removed the garbage and mowed the overgrown grass. We preserved the larger plants and left everything ready for planting.

At first, we started working on it ourselves. Overtime, other neighbors joined us, and soon we won the trust of some who shared our desire for recovering and revamping that space. There was no planning on what to cultivate, but as I had many aromatic seedlings at home, these were the first species to be planted, clove basil
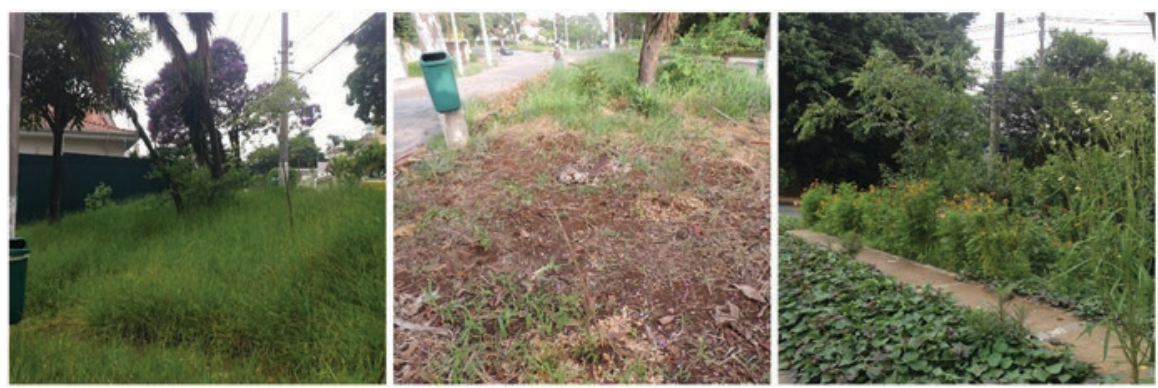

Fig. 1 Horta City Lapa in 2014 and in 2019. (Photos by Neide Rigo) 
(Ocimum gratissimum L.), manjericão-anis (Ocimum carnosum (Spreng.) Link \& Otto ex Benth), ruby leaf (Alternanthera brasiliana (L.) Kuntze), lemon grass (Cymbopogon citratus (DC.) Stapf), and sweet-scented geranium (Pelargonium graveolens L'Hér.), in addition to more common species such as rosemary, kale, etc.

Some of the plants proved unsuitable for the space we had, so we gradually replaced those. We came to that conclusion during our first winter. Summer rains were beneficial to our kitchen garden, as we never had any water source, but when the cold dry winter arrived, the garden suffered and lost a good portion of the species. Another decisive factor for the choice of plants that we would grow there was the interest aroused by some species. The garden is open and located in a place with considerable pedestrian traffic, so many of the plants were uprooted and taken away.

A natural selection slowly took place and defined the current configuration of the garden. At the same time, we had to deal with angry neighbors who did not want a public garden close to their homes. Their arguments were flawed and full of prejudice, but it was their best shot. They said that the work groups for the garden would attract strange people to our area; that the place had bad soil; that people who came and went to the nearby train station would take everything away; that what we were growing was not a garden as they knew it; that it was something of such bad taste it could not even be called a garden; that we did not have authorization from the city government to mess with public gardening; that people who eventually ate something grown there were at great risk; that we did not have technical knowledge to work with plants; and that we destroyed the sidewalk (which has never existed, it used to be just high grass), among other empty accusations. We were then called to the neighborhood council, where authorities tried to convince us to formally care for the garden (sort of an adoption). Our group was larger at that point, and we agreed to remain informal. After much nuisance and dried plants by the drought, summer rains calmed the spirits and outlined what would remain in our garden. By that time, our space received a plaque with a name honoring the neighborhood: "Horta City Lapa." Figure 2 shows some gardeners of our group.

It was then that we realized that although we did not plan it, the plants that today are part of the garden are those we call UFPs. They were the ones who could resist all bad weather, both meteorological conditions properly said and bad tempers, and they keep on firm and strong, come rain or sunshine.

As I write, we are still in quarantine due to COVID-19 pandemic and in the midst of a winter drought. Still we have perennial and rustic species that cross the seasons and also some very resistant annuals harvested in winter. In addition to the two types of Ocimum sp. already mentioned and various spontaneous seasonal species, we have chaya (Cnidoscolus aconitifolius (Mill.) I.M.Johnst.), moringa (Moringa oleifera L.), cinnamon (Cinnamomum verum J. Presl), bay leaves (Laurus nobilis L.), curry leaves (Murraya koenigii L. Spreng), banana (Musa sp.), elderberry (Sambucus nigra L.), Turk's turban (Malvaviscus arboreus Dill. Ex Cav.), leaf cactus (Pereskia aculeata Mill.), spiked spiralflag ginger (Costus spicatus (Jacq.) Sw.), boldão (Plectranthus grandis (L.H. Cramer) R.H. Willemse), boldinho (Plectranthus ornatus Codd.), arrowroot (Maranta arundinacea L.), turmeric (Curcuma longa L.), and sweet potato (Ipomoea batatas (L.) Lam.), among others. 


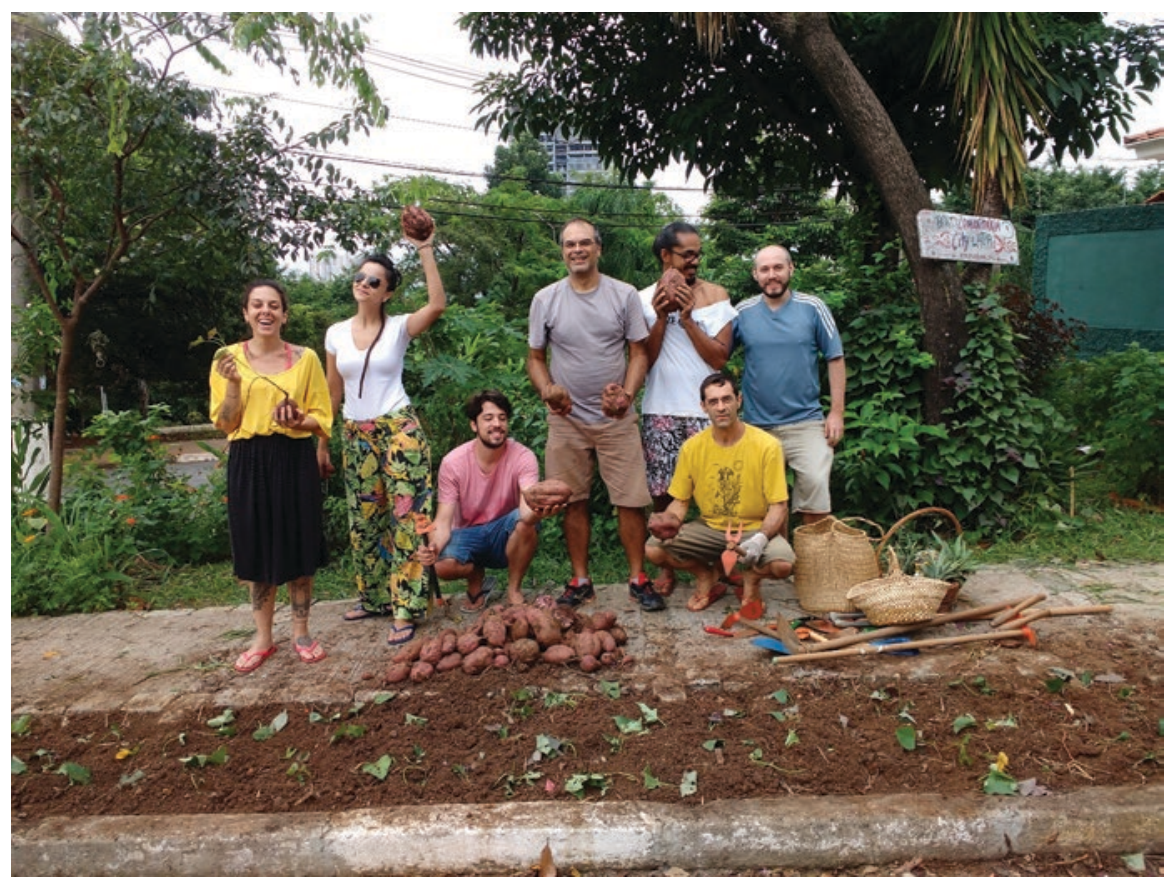

Fig. 2 Gardeners of Horta City Lapa after planting sweet potatoes. (Photos by Neide Rigo)

After all these years, the vegetable garden has become a reference on our street, and during normal times, it is a pleasant place to take children and maybe pick some herbs. I know that our garden is not an example of an urban agriculture with vast food production, but it certainly is an example of how a degraded space can be transformed into a useful garden that, in addition to providing a little food and aromatic and medicinal plants, also serves the purpose of reconnecting people with the ground and the cycles of nature. It also connects the local community, uniting them around a common will to make cities more humane, safe, and friendly.

The few neighbors who were unfavorable to our initiative are still around, but their voices were silenced in the face of the unquestionable benefits that a public garden brings to the neighborhood. Nowadays, daily care is given spontaneously by community volunteers and more intensely during task force days, when we join neighbors and people from other areas who are interested in helping.

I believe that the success of these experiences strengthens the idea that citizens occupying the public space make any city a safer and more pleasant place to live in, nourishing everyone's physical and mental health. And that any idle space can be transformed into a useful and low maintenance garden, if only we choose rustic and appropriately adapted species, the majority of which will surely be among the UFPs group. 
Finally, below I provide a list of references that can be useful as education resources to people interested in starting community-based projects with Brazilian UFP (Brasil 2019; Kinupp and Lorenzi 2014; Ranieri 2017, 2018; Rigo 2017). These references provide helpful guidance in identifying and cooking these plant species.

\section{References}

Brasil (2019) Amazônia à mesa: Receitas com produtos da sociobiodiversidade para a alimentação escolar. MAPA/SAF, Brasília/DF

Kinupp V, Lorenzi H (2014) Plantas Alimentícias Não Convencionais (Panc) no Brasil. Editora Plantarum, São Paulo

Ranieri G (2017) Guia prático de plantas alimentícias não convencionais. Instituto Kairós, São Paulo

Ranieri G (2018) Guia prático de plantas alimentícias não convencionais para escolas. Instituto Kairós, São Paulo

Rigo N (2017) Mesa farta no semiárido. COOPERCUC, Uauá/BA 